\title{
Helen Salisbury: Fear in the time of covid
}

\author{
Helen Salisbury GP \\ Oxford
}

While London's hospitals are already nearing capacity, many other areas are still in the "phoney war" stage of this pandemic. Never has so much work been done, so quickly, in so many hospitals. New critical care wards have been created, operating suites repurposed, and emergency departments completely reorganised to try to concentrate infective patients in one place. Changes that would usually have taken years of wrangling about money have happened in the space of a week, with superhuman efforts from healthcare workers and managers alike. I am in awe.

Our academic colleagues are also working in overdrive, rapidly synthesising evidence and getting it out to clinicians who need it. ${ }^{12}$ It's hard to keep up, but every piece of trusted information helps when struggling with an unfamiliar disease.

In general practice, we've changed our way of working. We've put off everything that can safely be postponed. The doors are locked, and patients set foot in the building only when it's clear that their problem can't be solved remotely and that they're deemed to be low risk.

But what is low risk? As asymptomatic shedding of the virus in the early stages seems to be the norm, and some people have only very mild symptoms for their entire illness, we can't be sure. From NHS supplies, we've received a delivery of 150 fluid resistant surgical masks and plastic aprons and gloves, which won't last long if we use them for every contact. Like many other practices we've been sourcing our own-scouring the internet for surgical scrubs, masks, goggles, and gowns-but supplies are drying up.
Most regions have plans to set up "hot hubs," where patients who need to be assessed face to face in primary care can be seen by a dedicated team. It's still not clear how these will operate, who will work there, or what will be done to minimise the risk to staff, and the learning curve will be steep. A serology test that could tell us who has already been infected and is therefore relatively immune would be hugely useful.

The emotional rollercoaster is a hard ride. Pride in our colleagues and their achievements is matched by anger at the government's failure to prioritise the testing, personal protective equipment, and ventilators we need. Many of us, knowing that our colleagues in hospital have no choice, are feeling cowardly that we haven't yet volunteered for the hubs.

Fear is all around-for ourselves, for our families, and for our patients. We know that some will die from covid-19 despite the best that modern medicine can offer. The bigger fear is that hospitals will be overwhelmed, as in Italy, bringing many more preventable deaths. I'm still trying to hold on to the hope that the increases in capacity, combined with reduced transmission from social distancing, will be enough.

Competing interests: See www.bmj.com/about-bmj/freelance-contributors. Provenance and peer review: Commissioned; not externally peer reviewed.

1 Centre for Evidence-Based Medicine. Oxford COVID-19 Evidence Service. https://www. cebm.net/covid-19/.

Greenhalgh T, Koh GCH, Car J. Covid-19: a remote assessment in primary care. BMJ 2020;368:m1182. 10.1136/bmj.m1182 32213507

Published by the BMJ Publishing Group Limited. For permission to use (where not already granted under a licence) please go to http://group.bmj.com/group/rights-licensing/ permissions 